\title{
Morphohistological and flow cytometric analyses of somatic embryogenesis in Trifolium nigrescens Viv.
}

\author{
Robert Konieczny • Elwira Sliwinska • \\ Maria Pilarska $\cdot$ Monika Tuleja
}

Received: 18 August 2011/Accepted: 22 October 2011/Published online: 10 November 2011

(C) The Author(s) 2011. This article is published with open access at Springerlink.com

\begin{abstract}
Microscopy and flow cytometry (FCM) were used to study somatic embryogenesis (SE) from zygotic embryos of Trifolium nigrescens Viv. to determine if there were any relationships between characteristics of somatic embryos (morphology, anatomy, genome size stability) and their regenerability. Embryoids were induced on Murashige and Skoog (MS) medium containing $4 \mathrm{mg} \mathrm{l}^{-1}$ 2,4-dichlorophenoxyacetic acid (2,4-D) and $2 \mathrm{mg} \mathrm{l}^{-1} \mathrm{~N}^{6}$-[2-isopentenyl]-adenine (2iP) either directly from hypocotyls or via an intervening callus, depending on the duration of culture. The morphology of somatic embryos varied from zygoticlike structures to abnormal structures including hornshaped, polycotyledonary, and fused embryoids. The incidence of abnormalities was higher in callus cultures than in direct regeneration. Horn-shaped embryoids were the most frequent type of abnormal embryos. Only embryoids having zygotic-like morphology regenerated into plantlets. Histological observations revealed that the absence of shoot and root apical meristems along with parenchymatization of embryos were major obstacles to conversion of horn-shaped embryoids. The estimated $2 \mathrm{C}$ value for $T$. nigrescens was $0.9 \mathrm{pg}$. FCM analysis revealed differences in DNA content between embryoids induced via an intervening callus and those produced directly from explants. Individuals with species-specific as well as increased DNA content were
\end{abstract}

R. Konieczny $(\bowtie) \cdot$ M. Pilarska $\cdot$ M. Tuleja

Department of Plant Cytology and Embryology, Jagiellonian

University, Grodzka St. 52, 31-044 Kraków, Poland

e-mail: robert.konieczny@uj.edu.pl

E. Sliwinska

Department of Plant Genetics and Biotechnology, Laboratory of Molecular Biology and Cytometry, University of Technology and Life Sciences, Kaliskiego Ave. 7, 85-789 Bydgoszcz, Poland detected among those zygotic-like embryos derived from callus, but all horn-shaped embryoids had increased genome sizes. The observed lack of differences in DNA content between zygotic-like and horn-shaped embryoids, from direct SE, indicated that these phenotypic abnormalities were of physiological origin. The mean DNA content of regenerants was species-specific, suggesting that only diploid embryoids were capable for regeneration into plantlets.

Keywords Auxin - Clover · Flow cytometry · Histology · Nuclear DNA content · Somatic embryo morphology
Abbreviations
2,4-D 2,4-dichlorophenoxyacetic acid
2iP $\quad \mathrm{N}^{6}$-[2-isopentenyl]-adenine
FCM Flow cytometry
MS Murashige and Skoog (1962) medium
SE Somatic embryogenesis
PGR Plant growth regulator

\section{Introduction}

Somatic embryogenesis (SE) is a process whereby a single plant cell or group of cells from somatic tissue forms an embryo. Ideally, somatic embryos are bipolar structures (with shoot and root meristems) containing a closed tracheal system and exhibiting morphological similarities to their zygotic counterparts (Gaj 2004). Some culture conditions, especially the concentration and type of plant growth regulators (PGRs) in the medium as well as the length of time that a tissue has been maintained in vitro, may affect somatic embryo quality, which in turn may 
hamper or even completely inhibit the further differentiation and/or growth of embryo-derived plants. Among the different PGRs, the auxinic herbicide 2,4-dichlorophenoxyacetic acid (2,4-D) has been recognized as a strong teratogenic agent. Culture on media containing 2,4-D has been directly linked to the production of phenotypically abnormal embryoids in legumes such as soybean (Lazzeri et al. 1987; Buchheim et al. 1989), pea (Őzcan et al. 1993) and peanut (Wetzstein and Baker 1993), and also in other species, among them cassava (Sofiari et al. 1997), pecan (Rodriguez and Wetzstein 1994, 1998) and Schisandra chinensis (Yang et al. 2011). Histology of aberrant embryos pointed to the absence of a well-defined shoot apical meristem and/or extensive unorganized proliferation of embryo cells as the most frequent reasons for a low conversion rate or the inability to regenerate plants (Suhasini et al. 1996; Rodriguez and Wetzstein 1998). In the genus Trifolium, production of aberrant embryoids has been reported in white clover (Parrott 1991) and more recently in T. nigrescens (Konieczny et al. 2010), but the anatomical basis of this phenomenon has not been examined as yet.

In some systems the occurrence of abnormal phenotypes during regeneration in vitro is correlated with genetic changes in cultured material (Fourré et al. 1997; Tremblay et al. 1999). Somaclonal variation in plant tissue culture can be manifested as cytological abnormalities, qualitative and quantitative phenotypic mutation, nucleotide sequence changes, and gene activation and silencing (Kaeppler et al. 2000). In legumes the presence of 2,4-D in the medium was implicated in the high incidence of somaclonal variation among alfalfa and soybean (Nagarajan and Walton 1987; Shoemaker et al. 1991). Ochatt et al. (2000) suggested an effect of exogenously applied PGRs on an increase of DNA content and resulting recalcitrance to plant regeneration in pea culture. Abnormalities in the DNA content of cultured explants were correlated with hyperhydricity during organogenesis, and with the reduced competence of such hyperhydric shoots for subsequent rooting and fertile plant production (Ochatt et al. 2003). Several methods have been developed to assess changes in DNA content in living cells. Among them, flow cytometry (FCM) is considered one of the best because it is quick, highly accurate, and requires only a small amount of tissue for analysis (Doležel and Bartoš 2005). FCM has been successfully employed to assess somaclonal variation during both $\mathrm{SE}$ and organogenesis of a number of plants (e.g., Prado et al. 2010; LemaRumińska 2011; Ghimre et al. 2011). In culture of cork oak (Loureiro et al. 2005) and maritime pine (Marum et al. 2009a) it was used to verify DNA content in phenotypically normal and abnormal somatic embryos. Very little effort has been devoted to analyses of somaclonal variation in clovers produced in vitro. Changes in chromosome number were reported in red clover (Wang and Holl 1988) and Berseem clover (Masoud and Hamta 2008) regenerated via organogenesis. The relationships between somatic embryo phenotype, nuclear DNA content and the ability to develop into plants has not been studied in Trifolium.

Trifolium nigrescens (Viv.) is a self-incompatible diploid $(2 n=2 x=16)$ used as a forage legume for pasture and soil improvement (Hoveland and Evers 1995). Previously we demonstrated that 2,4-D is a more potent inducer of somatic embryos than NAA in this plant, but embryoids obtained in the presence of 2,4-D displayed morphological abnormalities and a reduced ability to regenerate plants (Konieczny et al. 2010). That study did not focus on quantitative data related to normal and abnormal embryoid production or to the relationship between embryo morphology and plant regeneration. In our studies of SE in T. nigrescens our attention is now directed to morphohistological and genetic analyses of phenotypically normal and abnormal embryoids obtained on medium containing 2,4-D. FCM and different microscopy techniques are used in combination to determine the possible cytological and anatomical reasons for their disturbed ontogeny and difficulties in plant regeneration.

\section{Materials and methods}

\section{Plant material and culture procedure}

Seeds of Trifolium nigrescens (Viv.) ssp. nigrescens were kindly provided by the Institute of Plant Genetics and Crop Plant Research, Gatersleben, Germany. The procedures for donor plant growth, explant preparation and culture conditions were as described previously (Konieczny et al. 2010). Briefly, somatic embryos were induced from immature zygotic embryos at cotyledonary stage (ca $3 \mathrm{~cm}$ long) on Murashige and Skoog (1962) basal medium (MS) containing $30 \mathrm{~g} \mathrm{l}^{-1}$ sucrose, $8 \mathrm{~g} \mathrm{l}^{-1}$ agar, $2 \mathrm{mg} \mathrm{l}^{-1} \mathrm{~N}^{6}$-[2isopentenyl]-adenine (2iP) and $4 \mathrm{mg} \mathrm{l}^{-1}$ 2,4-dichlorophenoxyacetic acid (2,4-D), pH 5.7. In total, 250 zygotic embryos were cultured, 10 per Petri dish $(100 \times 20 \mathrm{~mm})$. After 2 and 8 weeks of culture on induction medium the somatic embryos that occurred on the original explants were counted under a stereomicroscope and categorized in morphological classes according to shape, symmetry, number of cotyledons and the occurrence of fused embryos. The frequency of a given class of somatic embryos was expressed as the percentage of 480 and 645 embryoids that occurred on 50 explants randomly taken for assay after 2 and 8 weeks of culture, respectively. At the same time the mean number of somatic embryos produced per explant (total number of 
embryoids of particular morphological class/number of explants showing SE) was calculated. After counting, somatic embryos having typical zygotic-like morphology and horn-shaped ones were harvested from the original explant and used for histological observations and ploidy stability analysis by FCM. Additionally, 25 embryoids of each morphological class were removed from explants and transferred individually to PGR-free MS for 10 weeks ( 5 somatic embryos per $60 \times 20 \mathrm{~mm}$ Petri dish) to assess their germinability. The experiment was repeated 4 times. All in vitro cultures were maintained in a growth chamber at $25 \pm 2{ }^{\circ} \mathrm{C}$ under cool white fluorescent light $(80 \mu \mathrm{mol}$ $\mathrm{m}^{-2} \mathrm{~s}^{-1}$ ) with a $16 \mathrm{~h}$ photoperiod. Unless stated otherwise, the chemicals used in the experiments were purchased from Sigma (Germany).

\section{Light microscopy}

Material for light microscopy observations was collected daily from days 0 to 14 of culture and after 5, 6 and 8 weeks on induction medium. In total, 15 somatic embryos of zygotic-like appearance and 15 embryoids of horn-shaped morphology were taken for assay at each time point. Fixation and embedding followed procedures described earlier (Konieczny et al. 2003). Sections (5 $\mu \mathrm{m}$ thick) were stained with toluidine blue or the periodic acidSchiff (PAS) reaction to reveal starch and other insoluble polysaccharides.

\section{Scanning electron microscopy}

Material for scanning electron microscopy (SEM) studies (15 somatic embryos of zygotic-like morphology and 15 horn-shaped embryoids) was taken at days 0, 3, 5, 9, 14 and after 5, 6 and 8 weeks of culture on induction medium. Samples were prefixed in $5 \%$ buffered glutaraldehyde (0.1 M phosphate buffer, $\mathrm{pH}$ 7.2) for $2 \mathrm{~h}$ and then postfixed in $1 \%$ buffered $\mathrm{OsO}_{4}(0.1 \mathrm{M}$ phosphate buffer, $\mathrm{pH}$ 7.2) for $2 \mathrm{~h}$ at room temperature. After dehydration through a graded ethanol series (15\% increments every $30 \mathrm{~min}$ ) the material was critical-point dried (LADD critical point dryer), sputter-coated with gold (Jeol JFC-1100 E ionsputtering system) and observed with a scanning electron microscope (Hitachi S-4700) at $20 \mathrm{kV}$.

\section{Flow cytometry}

FCM analyses used material from in vitro cultures and plants growing in vivo. Zygotic embryos were assayed on day 7 on induction medium, somatic embryos of zygotic embryo-like morphology and abnormal horn-shaped embryoids after 2 and 8 weeks of culture on induction medium, and leaves of regenerated plantlets after 10 weeks on PGR-free MS. On a given day, 10 zygotic embryos and 10 somatic embryos of zygotic-like and 10 of horn-shaped morphology taken from 10 different explants were analyzed. To establish nuclear DNA content in regenerated plantlets, 3 leaves were collected from 10 different plantlets obtained from somatic embryos. The control consisted of 12 zygotic embryos before culture and 12 leaves collected from 3 different plants growing in vivo (conditions for growth of mother plants as described in Konieczny et al. 2010). Petunia hybrida $(\mathrm{P} \times$ Pc6; 2.85 pg/2C, Marie and Brown 1993) was used as internal standard. Plant material was chopped with a sharp razor blade in a plastic Petri dish with $1 \mathrm{ml}$ nucleus isolation buffer $\left(0.1 \mathrm{M}\right.$ Tris, $2.5 \mathrm{mM} \mathrm{MgCl}_{2} \cdot 6 \mathrm{H}_{2} \mathrm{O}, 85 \mathrm{mM} \mathrm{NaCl}$, $0.1 \%(\mathrm{v} / \mathrm{v})$ Triton X-100) supplemented with propidium iodide $\left(50 \mu \mathrm{g} \mathrm{ml}^{-1}\right)$ and ribonuclease $\mathrm{A}\left(50 \mu \mathrm{g} \mathrm{ml}^{-1}\right)$. The suspension was passed through a $50 \mu \mathrm{m}$ mesh nylon filter. For each assayed sample, fluorescence was measured in 1,000-5,000 nuclei using a CyFlow SL Green (Partec $\mathrm{GmbH}$, Münster, Germany) flow cytometer equipped with a high-grade solid-state laser with green light emission at $532 \mathrm{~nm}$, long-pass filter RG 590 E, DM 560 A, and side (SSC) and forward (FSC) scatter. Histograms were analyzed with FloMax software (Partec GmbH, Münster, Germany). The coefficient of variation $(\mathrm{CV})$ of the $\mathrm{G}_{0} / \mathrm{G}_{1}$ peak of T. nigrescens ranged between 4.6 and $8.46 \%$. Nuclear DNA content was calculated using the linear relationship between the ratio of the $2 \mathrm{C}$ peak positions of Trifolium/Petunia on the histogram of fluorescence intensities.

Statistical analysis

The significance of results from in vitro cultures and FCM analyses was checked by one-way ANOVA and Duncan's test $(P \leq 0.05)$ in Statistica for Windows ver. 8.0 (StatSoft, Inc. Tulsa, U.S.A.).

\section{Results}

Morphology and germination of somatic embryos

Somatic embryos appeared as globular structures (Fig. 1a) proliferating directly from the hypocotyl of explanted embryos at days 7-12 of culture or indirectly from embryoderived callus after 18 days of culture. The frequency of SE was $65 \%$ for direct and $100 \%$ for indirect regeneration. Once induced, embryoids elongated and either developed as bipolar structures resembling heart-, torpedo- and cotyledon-stage zygotic embryos (Fig. 1b-e) or showed disturbed development leading to different morphological abnormalities. Most of the abnormal embryos were hornshaped with collar-like cotyledons (Fig. 1f-h). During their development the heart stage was not observed; the 
Fig. 1 SEM micrographs of SE from zygotic embryos of T. nigrescens. a-e Development of embryoids of zygotic embryo-like phenotype. Globular (a), heart- (b), torpedo- (c) and cotyledonarystage (d, e) embryoids obtained directly from hypocotyl; $\mathbf{f}-\mathbf{j}$ morphological classes of abnormal somatic embryos obtained directly (f, g) and indirectly (h-j). Young (f) and more mature $(\mathbf{g}, \mathbf{h})$ horn-shaped somatic embryos. Arrowhead indicates early stages of the formation of a cotyledonary ring with an apical pore (f) and the swelled regions of an embryoid hypocotyl (g); i somatic embryos with fused embryo axis; $\mathbf{j}$ polycotyledonary somatic embryo; $\mathbf{k}$ developing somatic embryo of zygoticembryo-like phenotype. Bar $=50 \mu \mathrm{m}(\mathbf{a}-\mathbf{j}) ; 3 \mathrm{~mm}(\mathbf{k})$
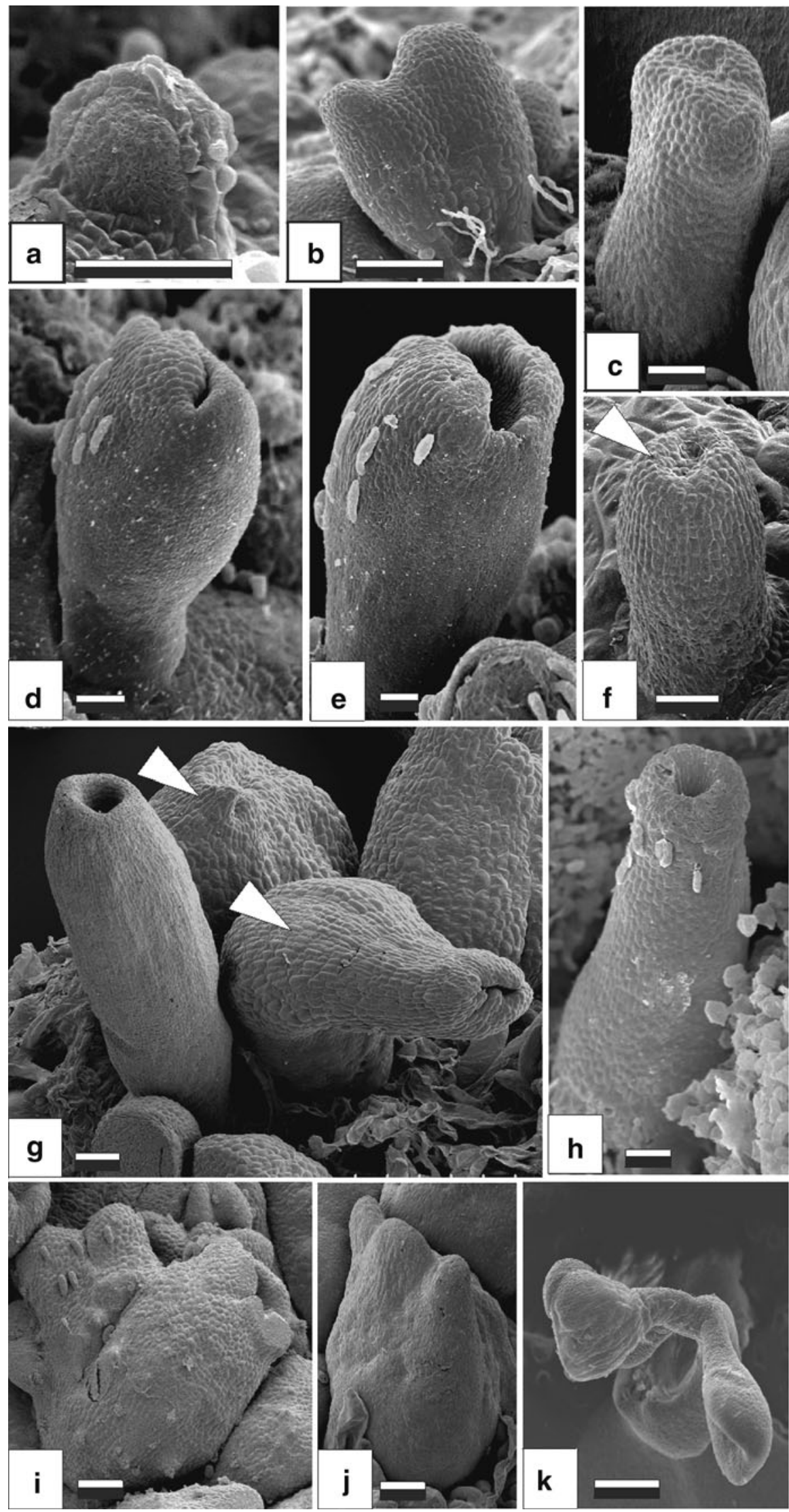
Table 1 Somatic embryo morphology and development in zygotic embryo culture of $T$. nigrescens

\begin{tabular}{|c|c|c|c|c|c|c|}
\hline \multirow{3}{*}{$\begin{array}{l}\text { Morphology of } \\
\text { embryoids }\end{array}$} & \multicolumn{6}{|c|}{ Time of culture on induction medium/origin of embryoids } \\
\hline & \multicolumn{3}{|c|}{2 weeks/direct SE } & \multicolumn{3}{|c|}{8 weeks/indirect SE } \\
\hline & $\begin{array}{l}\% \text { of total } \\
\text { embryoid }\end{array}$ & $\begin{array}{l}\text { Embryoids/ } \\
\text { explant } \pm \mathrm{SD}\end{array}$ & $\begin{array}{l}\% \text { of } \\
\text { conversion } \pm \mathrm{SD}\end{array}$ & $\begin{array}{l}\% \text { of total } \\
\text { embryoid }\end{array}$ & $\begin{array}{l}\text { Embryoids/ } \\
\text { explant } \pm \text { SD }\end{array}$ & $\begin{array}{l}\% \text { of conversion } \\
\pm \mathrm{SD}\end{array}$ \\
\hline Zygotic-like & 64 & $7.2 \pm 1.21 \mathrm{a}$ & $36 \pm 6.2$ & 31 & $6.0 \pm 0.91 \mathrm{a}$ & $12 \pm 2.4$ \\
\hline Horn-shaped & 36 & $2.4 \pm 0.89 \mathrm{~b}$ & 0 & 64 & $6.1 \pm 1.24 \mathrm{a}$ & 0 \\
\hline Fused & 0 & 0 & 0 & 2 & $0.6 \pm 0.02 b$ & 0 \\
\hline Polycotyledonary & 0 & 0 & 0 & 3 & $0.2 \pm 0.14 b$ & 0 \\
\hline
\end{tabular}

Values within a column followed by the same letter do not significantly differ at $P \leq 0.05$ (Duncan's test)

cotyledons formed circularly around a centrally located apical pore. Initially the horn-shaped embryoids were elongated structures of similar thickness along the entire length. However, as they matured the basal part swelled significantly, giving the embryo a barrel-like appearance (Fig. 1g, arrowhead). Also observed in addition to hornshaped embryoids were somatic embryos with supernumerary cotyledons and/or fused embryo axes, but they were very infrequent (Fig. 1i, j; Table 1). The mean number of zygotic-like embryos produced per explant was similar in direct and indirect regeneration (7.2 per hypocotyl, 6.0 per callus), but more than twice as many horn-shaped embryoids were produced indirectly (6.1 per callus) as directly (2.4 per hypocotyl). Fused and polycotyledonary embryos occurred only indirectly, with similar frequencies: 0.6 and 0.2 per callus, respectively (Table 1 ). The embryoids of abnormal phenotypes swelled significantly when maintained continuously on induction medium or after subculture on PGR-free MS. Roots or shoots never formed, and the embryos died within about 3 weeks after they appeared. In contrast, somatic embryos showing zygotic embryo-like morphology could germinate and develop into seedlings after transfer to PGR-free MS medium (Fig. 1k). Germination frequency was related to embryo origin, and was 3 times higher in direct regeneration than in indirect embryogenesis (Table 1). Subculture on PGR-free MS was required for further development of somatic embryos: with continued culture on induction medium they became malformed and either died or produced nonregenerative callus.

\section{Histology of SE}

The hypocotyl of initial explants consisted of a single-layer epidermis, 4-5-layers of cortex and vascular cylinder (Fig. 2a). All the cells of the hypocotyl were tightly packed, had darkly stained cytoplasm and a centrally located nucleus. No dividing cells were observed within the hypocotyl before explantation. After 3 days of culture, meristematic activity occurred in the vascular cylinder and cortex, followed by the formation of meristematic swellings at the periphery of the hypocotyl by day 7 (Fig. 2b, c). The hypocotyl epidermis remained intact while these swellings were forming. Globular embryoids differentiated from epidermal/subepidermal cells of meristematic protrusions. They were always broadly attached to mother tissue and covered by the epidermis of the initial explant (Fig. 2d). When developing according to zygotic embryogenesis, the embryoids differentiated separate cotyledonary primordia, followed by the formation of distinct root and shoot meristems and provascular strands passing to two cotyledons (Fig. 2e-g). The cells of mature embryos were almost devoid of starch (Fig. 2g).

Unlike somatic embryos having typical morphology, the horn-shaped embryoids never produced root and shoot meristems (Fig. 2h, i). Figure $2 \mathrm{~h}$ shows horn-shaped embryos 7 and 14 days after induction. Initially these embryos were composed of small tightly packed cells, rectangular at the basal part and isodiametric at the apical part of the embryo body. Tracheary elements were not observed, but putative initials of vascular strands could be identified by a narrow zone of small rectangular cells in the central part of the embryo axis (Fig. 2h, arrowhead). Aging of the embryoids was accompanied by conspicuous cell enlargement within the hypocotyl. Cotyledons were poorly defined, and in extreme cases one or both cotyledons were entirely lacking. When formed, however, the cotyledons consisted of cells with more starch than those within the hypocotyl (Fig. 2h, inset). With continued culture the embryos became parenchymatous structures composed of large starch-bearing cells of irregular shape and cytoplasm faintly stained or even not staining by toluidine blue (Fig. 2i-k). Sporadically, a broad, irregularly shaped zone of small cells with densely stained cytoplasm was produced at the embryo base (Fig. 2i, star), but neither root meristems nor root caps were confirmed histologically. Vascular strands were not detected in mature horn-shaped embryos.

After 12 days of culture, extensive cell proliferation within the hypocotyl resulted in numerous cone- or domeshaped swellings at its periphery, followed by rupture of 

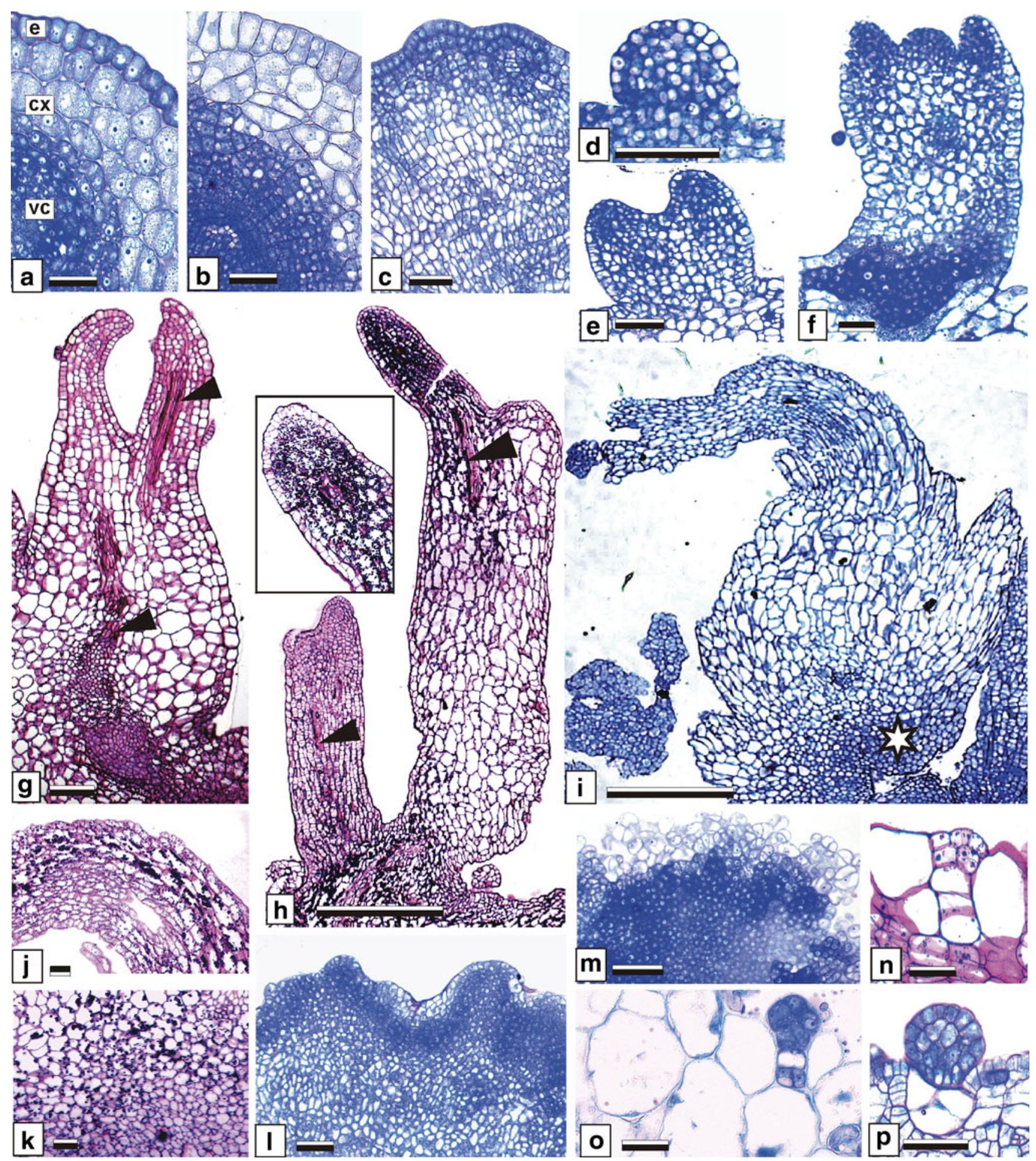

Fig. 2 Histology of SE from zygotic embryos of $T$. nigrescens. Transverse sections through hypocotyl at day 0 (a) and after 3 (b) and 7 (c) days of culture; $e$ : epidermis, $c x$ : cortex; $v c$ : vascular cylinder; d-g development of embryoids of zygotic embryo-like morphology. Globular (d), heart- (e) and cotyledonary-stage (f, g) somatic embryos. Arrowheads indicate vascular strands; $\mathbf{h}-\mathbf{k}$ development of horn-shaped embryoids. h Young and more mature horn-shaped embryoids with single cotyledon. Arrowheads indicate vascular strands; i mature horn-shaped embryo with thickened basal part. Star indicates zone of meristematic cells; $\mathbf{j}, \mathbf{k}$ High magnification of embryoid from $\mathbf{i}$, stained to reveal starch; $\mathbf{l}-\mathbf{p}$ callus formation and early stages of indirect SE. I Production of endogenous callus; $\mathbf{m}$ heterogenous callus composed of large parenchymatous cells at the periphery and compact meristematic tissue in central part; $\mathbf{n}-\mathbf{o}$ fewcelled embryoids embedded in external parenchyma of callus; $\mathbf{p}$ globular embryo at periphery of callus. Sections in $\mathbf{a}-\mathbf{f}, \mathbf{i}, \mathbf{l}$, $\mathbf{m}-\mathbf{p}$ stained with toluidine blue; sections in $\mathbf{g}, \mathbf{h}, \mathbf{j}, \mathbf{k}, \mathbf{n}$ with PAS reaction. Bar $=50 \mu \mathrm{m}(\mathbf{a}-\mathbf{g}, \mathbf{j}-\mathbf{p}) ; 500 \mu \mathrm{m}(\mathbf{h}, \mathbf{i})$ 
Fig. 3 Selected DNA histograms of nuclear preparations of Petunia hybrida (internal standard) leaves and zygotic embryos, somatic embryos and leaves of regenerated plantlets of Trifolium nigrescens. a zygotic embryos before culture; b zygotic-like somatic embryos obtained directly; c horn-shaped somatic embryos obtained directly; d zygotic-like somatic embryos obtained indirectly; e horn-shaped somatic embryos obtained indirectly; $\mathbf{f}$ leaves of regenerated plantlets via callus
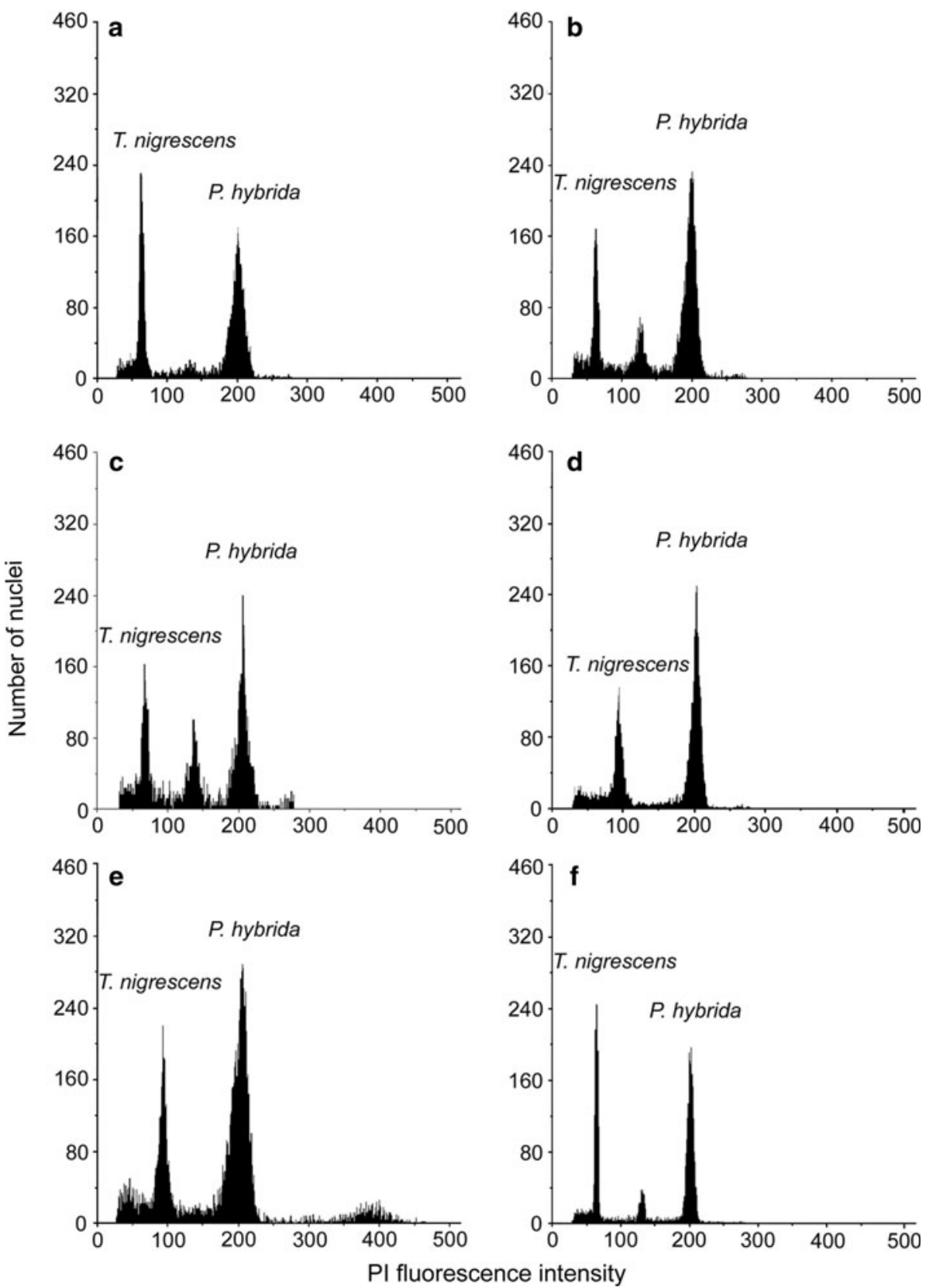

the epidermis and outgrowth of callus over the explant surface (Fig. 21, m). Initially the callus was heterogenous in structure: large, loosely attached parenchyma cells were observed at its periphery, while the inner regions were occupied by compact meristematic tissue (Fig. 2m). Fewcelled structures closely resembling proembryos became visible after 18 days of culture. They were located at the callus periphery and often contained a suspensor-like cell cluster which was embedded in highly vacuolated callus cells (Fig. 2n, o). The globular embryoids of callus origin were surrounded by protoderm clearly separating them from surrounding nonembryogenic tissue (Fig. 2p). Further development of callus-derived globular embryoids leading to zygotic-like and horn-shaped ones followed the pattern described above for direct regeneration (data not shown).

FCM analysis

The genome sizes of $T$. nigrescens estimated by FCM in different plant material ranged from ca. 0.9 to $1.85 \mathrm{pg} / 2 \mathrm{C}$ (Fig. 3). The nuclear DNA content of control material was $0.885 \mathrm{pg} / 2 \mathrm{C}$ for leaves from field-grown donor plants and $0.908 \mathrm{pg} / 2 \mathrm{C}$ for zygotic embryos before culture (Fig. 3; Table 2). After 7 days of culture the amount of DNA in nuclei of zygotic embryos did not change versus the control; nor were there significant differences between the 
Table 2 Mean nuclear DNA content of $T$. nigrescens field-grown plants, zygotic embryos at the time of explanting, somatic embryos differing in morphology and origin, and leaves of regenerated plantlets

\begin{tabular}{ll}
\hline Material & DNA content $(\mathrm{pg} / 2 \mathrm{C} \pm \mathrm{SD})$ \\
\hline Leaves of donor plant & $0.885 \pm 0.005 \mathrm{c}$ \\
Zygotic embryos before culture & $0.908 \pm 0.059 \mathrm{c}$ \\
Zygotic embryos 7 days in culture & $0.975 \pm 0.048 \mathrm{c}$ \\
Somatic embryos obtained directly & \\
$\quad$ Zygotic-like & $0.898 \pm 0.015 \mathrm{c}$ \\
$\quad$ Horn-shaped & $0.923 \pm 0.019 \mathrm{c}$ \\
Somatic embryos obtained indirectly & \\
$\quad$ Zygotic-like & $1.139 \pm 0.226 \mathrm{~b}$ \\
$\quad$ Horn-shaped & $1.413 \pm 0.202 \mathrm{a}$ \\
Leaves of regenerated plantlets & \\
$\quad$ Direct SE & $0.909 \pm 0.009 \mathrm{c}$ \\
Indirect SE & $0.908 \pm 0.015 \mathrm{c}$
\end{tabular}

Values followed by the same letter do not significantly differ at $P \leq 0.05$ (Duncan's test)

control and directly produced embryoids of zygotic embryo-like and horn-shaped morphology. In the cells of somatic embryos induced indirectly the amount of DNA was higher, reaching mean values of $1.139 \mathrm{pg} / 2 \mathrm{C}$ for normal and $1.413 \mathrm{pg} / 2 \mathrm{C}$ for horn-shaped embryos. It is noteworthy that in somatic embryos obtained directly there were a considerable number of $\mathrm{G}_{2}$ nuclei, which were not present in embryos obtained indirectly (Fig. 3b, c; second peak). This can speak for high cell cycle activity in these embryos. The high standard deviation estimated for callusderived embryos $(\mathrm{SD}>0.2)$ reflects the wide range of $2 \mathrm{C}$ DNA values among the assayed embryos. Six zygotic-like somatic embryos showed DNA content similar to the control (ca $0.9 \mathrm{pg} / 2 \mathrm{C}$ ) and 4 showed increased DNA content (from 1.275 to $1.386 \mathrm{pg} / 2 \mathrm{C}$ ). None of the horn-shaped embryos obtained via callus had species-specific DNA content. The $2 \mathrm{C}$ value of these embryoids ranged between 1.265 and 1.857 , but only one embryoid had double the amount of DNA (tetraploid) as leaves of field-grown donor plants. The leaves of all regenerated plantlets growing in vitro had nuclear DNA content similar to the control.

\section{Discussion}

In the presence of 2,4-D and 2iP, zygotic embryos of T. nigrescens produced embryoids differing in morphology, nuclear DNA content and plant regeneration ability. Different somatic embryo phenotypes, including morphologically "normal" zygotic-like embryoids and aberrant structures (horn-shaped, polycotyledonary and fused embryos) were induced concurrently on the same explant/callus, with the frequencies depending on the duration of culture on induction medium. Abnormalities of cotyledon development and fusion of the embryo axis have been observed in SE of several legumes, including soybean (Ranch et al. 1986; Buchheim et al. 1989), chickpea (Suhasini et al. 1996) and pea (Griga 2002), and have been related to 2,4-D exposure. In Trifolium, Parrott (1991) reported poorly developed cotyledons in most of the white clover embryoids induced by 2,4-D. In his study there was no relationship observed between the duration of 2,4-D treatment and embryo quality, while in our experiments the incidence of abnormalities increased with the duration of culture. 2,4-D has been suggested to disturb polar auxin transport, which is a prerequisite for the establishment of bilateral symmetry and proper cotyledon differentiation (Gaj 2004). In the development of horn-shaped T. nigrescens embryoids the heart-shaped stage was omitted and the globular embryoids elongated, followed by the production of collarlike cotyledons. This pattern of embryo development has been observed before in pea (Griga 2002) and Brassica juncea (Hadfi et al. 1998), and was suggested to be a direct result of inhibition of polar auxin transport in the late globular embryo, where cotyledon primordia are initiated.

2,4-D has been shown to induce somaclonal variation, which in some plants was correlated with phenotypic diversity of somatic embryos (Fourré et al. 1997; Tremblay et al. 1999). The nuclear DNA content of our field-grown plants of $T$. nigrescens was ca $0.9 \mathrm{pg} / 2 \mathrm{C}$, slightly higher than previously reported for this species $(0.789 \mathrm{pg} / 2 \mathrm{C}$; Vižintin et al. 2006); the latter value was established using T. repens as internal standard and a different nucleus isolation buffer. The nuclear DNA content of somatic embryos of $T$. nigrescens increased with the duration of culture, but with no observed relationship between the phenotype and nuclear DNA content in embryoid cells. These results are similar to those reported by Loureiro et al. (2005) and Marum et al. (2009a, b), and suggest that the origin of phenotypic abnormalities in SE of T. nigrescens is physiological. The literature data related to the genetic status of single somatic embryos are sparse and not uniform. Somatic embryos of cork oak (Loureiro et al. 2005) and broccoli (Yang et al. 2010) were found to have the same DNA content as mother plants. In Pinus pinaster there was no difference in the genome size of zygotic and somatic embryos (Marum et al. 2009a). Zygotic embryos of Eucalyptus globulus possessed less DNA then zygotic ones (Pinto et al. 2004), and embryoids of melon (Ezura and Oosawa 1994) and Norway spruce (Fourré et al. 1997) gave a wide range of chromosome numbers. The risk of somaclonal variation is suggested to be higher when somatic embryos are multicellular in origin (Gaj 2004). Developmental events accompanying direct SE in $T$. $n i$ grescens, such as budding of epidermal and subepidermal cells of initial explants before embryoid initiation, as well as broad attachment of somatic embryos to the parent 
tissue, closely resemble those reported in white clover (Maheswaran and Williams 1985) and suggest a multicellular pathway of development. On the other hand, the induction of few-celled somatic embryos in a mass of nonregenerative parenchyma cells of callus indicates the unicellular origin of indirectly produced embryoids. In our study, embryoids showing a species-specific DNA amount were obtained both from hypocotyl and from callus, while those showing elevated DNA levels were found only on callus. This seems to indicate that the origin of somatic embryos in T. nigrescens (single- or multi-celled) does not imply their DNA content, which in turn is related, apparently, to the duration of in vitro culture and/or callus proliferation per se. Callus culture is often accompanied by induction of severe cytological abnormalities such as aneuploidy and polyploidy, which increase with duration of culture (Coutos-Thevenot et al. 1990; Moyne et al. 1993; Rival et al. 1997; Kevers et al. 1999).

In our experiment only embryoids of zygotic-like morphology converted to plantlets; those with abnormal phenotypes did not develop further. Production of shoot and root apices has been suggested to be a prerequisite for successful somatic embryo recovery (Gaj 2004). Indeed, in our work the horn-shaped $T$. nigrescens embryoids lacked shoot and root meristems, but those of zygotic-like appearance had well-defined shoot and root apices. Hornshaped chickpea and cotton embryoids lacking shoot meristems were also unable to convert to plants, and these abnormalities were attributed to the teratogenic effect of 2,4-D (Suhasini et al. 1996; Hussain et al. 2009). In $T$. nigrescens the horn-shaped embryos died when maintained continuously on induction medium or even when transferred to MS without PGRs. The mechanism underlying this phenomenon remains unknown in polycotyledonary and fused embryos, but the histology of horn-shaped embryoids revealed severe disturbance of cell differentiation during embryo maturation. Prolonged exposure to phenoxyacetic acids such as 2,4-D can affect tissue development (Gaj 2004). Unlike in embryoids of zygoticlike morphology, the initials of provascular strands of hornshaped embryos were lost with embryo aging, and the ground embryo tissue turned into homogenous, vacuolized parenchyma. Although a zone of meristematic cells occurred at the base of some embryoids, neither root meristems or roots were ever produced. This suggests that the formation of this meristematic region was the result of unorganized cell proliferation rather than a step towards organized structure. Generally, our histological evaluations indicate that the lack of apical meristems was not the only cause of the observed inability of horn-shaped embryos to convert, and that it is also attributable to successive parenchymatization of tissue, with concomitant inhibition of vascularization.
The zygotic-like somatic embryos of $T$. nigrescens obtained on callus converted to plantlets with a frequency 3 times lower than embryoids obtained via direct embryogenesis from hypocotyl. FCM showed that about a third of the "normal" embryoids induced indirectly had increased DNA content, while these regenerated directly had DNA content comparable to the control. Changes in the DNA level of material cultured in vitro have been shown to affect plant regeneration. Polyploidization was accompanied by the loss of regenerative competence in SE of cucumber (Ezura and Oosawa 1994) and in organogenic cultures of pear (Sun et al. 2011). Embryogenic explants of grass pea and Medicago truncatula showed true-to-type DNA content, while nonregenerative ones had higher nuclear DNA (Ochatt et al. 2000; Ochatt 2008). In those studies and also in Kalanchoe (Varga et al. 1988) the loss of regeneration competence was suggested to be related to genome instability due to exposure to exogenous PGRs including 2,4-D. Nuclear DNA content is an important biological parameter known to affect various phenotypic characters, phenology and ecological behavior (Ochatt et al. 2011). Previously, we reported that root meristem cells of regenerants of $T$. nigrescens had a chromosome complement typical for the species (Konieczny et al. 2010). In agreement with those data, we found no differences in DNA amount between regenerated plantlets in the present work. This lack of differences in DNA content among regenerants, together with the variation of DNA content between individual $T$. nigrescens embryoids, may indicate that only somatic embryos with ca $0.9 \mathrm{pg} / 2 \mathrm{C}$ germinated and converted into plantlets. Indeed, the literature gives some data indicating that explants with a species-specific DNA level regenerate more readily than those with higher DNA amount (e.g., Sanchez et al. 1988; Ochatt et al. 2000; Elmaghrabi and Ochatt 2006). However, when using FCM one should keep in mind that this technique allows to measure only relatively large differences in nuclear DNA content (higher than 1\%; Pfosser et al. 1995), and therefore the presence of a low level of aneuploidy in the plant material studied here cannot be excluded.

Both the DNA content and morphological traits of T. nigrescens somatic embryos are good indicators of their regenerative potential. Future efforts to optimize SE in this species will address manipulation of culture conditions to improve the quality of somatic embryos and their ability to regenerate plants and also evaluation of the genetic stability of embryoids and regenerated plantlets using molecular biology methods.

Acknowledgments We thank the Institute of Genetics and Crop Plant Research (Gatersleben, Germany) for providing T. nigrescens seeds for this study. 
Open Access This article is distributed under the terms of the Creative Commons Attribution Noncommercial License which permits any noncommercial use, distribution, and reproduction in any medium, provided the original author(s) and source are credited.

\section{References}

Buchheim JA, Colburn SM, Ranch JP (1989) Maturation of soybean somatic embryos and the transition to plantlet growth. Plant Physiol 89:768-775

Coutos-Thevenot P, Jouanneau JP, Brown S, Petiard V, Guern J (1990) Embryogenic and non-embryogenic cell lines of Daucus carota cloned from meristematic cell clusters: relation with cell ploidy determined by flow cytometry. Plant Cell Rep 8:605-608

Doležel J, Bartoš J (2005) Plant DNA flow cytometry and estimation of nuclear genome size. Ann Bot 95:1-10

Elmaghrabi A, Ochatt S (2006) Isoenzymes and flow cytometry for the assessment of true-to-typeness of calluses and cell suspensions of barrel medic prior to regeneration. Plant Cell Tissue Org Cult 85:31-43

Ezura H, Oosawa K (1994) Ploidy of somatic embryos and the ability to regenerate plantlets in melon (Cucumis melo L.). Plant Cell Rep 14:107-111

Fourré JL, Berger P, Niquet L, Andre P (1997) Somatic embryogenesis and somaclonal variation in Norway spruce: morphogenic, cytogenetic and molecular approaches. Theor Appl Genet 94: $159-169$

Gaj MD (2004) Factors influencing somatic embryogenesis induction and plant regeneration with particular reference to Arabidopsis thaliana (L.) Heynh. Plant Growth Regul 43:27-47

Ghimre KB, Yu CY, Chung I (2011) Direct shoot organogenesis and assessment of genetic stability in regenerants of Solanum aculeatissimum Jacq. Plant Cell Tissue Org Cult [Published online 4 October 2011]

Griga M (2002) Morphology and anatomy of Pisum sativum somatic embryos. Biol Plan 45:173-192

Hadfi K, Speth V, Neuhaus G (1998) Auxin-induced developmental patterns in Brassica juncea embryos. Development 125:879-887

Hoveland CS, Evers GW (1995) Arrowleaf, crimson and other annual clovers. In: Barnes RF, Miller DA, Nelson CJ (eds) Forages, vol 1, 5th edn. An Introduction to Grassland Agriculture. Iowa State University Press, Ames, Iowa, pp 249-260

Hussain SS, Rao AQ, Husnain T, Riazuddin S (2009) Cotton somatic embryo morphology affect its conversion into plants. Biol Plant 53:307-311

Kaeppler SM, Kaeppler HF, Rhee Y (2000) Epigenetic aspects of somaclonal variation in plants. Plant Mol Biol 43:179-188

Kevers C, Greimers R, Franck T, Bisbis T, Dommes J, Gaspar I (1999) Flow cytometry estimation of nuclear size and ploidy level of habituated calli of sugar beet. Biol Plant 42:321-332

Konieczny R, Czaplicki AZ, Golczyk H, Przywara L (2003) Two pathways of plant regeneration in wheat anther culture. Plant Cell Tissue Org Cult 73:177-187

Konieczny R, Pilarska M, Tuleja M, Salaj T, Ilnicki T (2010) Somatic embryogenesis and plant regeneration in zygotic embryos of Trifolium nigrescens (Viv.). Plant Cell Tissue Org Cult 100: 123-130

Lazzeri PA, Hildebrand DF, Collins GB (1987) Soybean somatic embryogenesis: effects of hormones and culture manipulations. Plant Cell Tissue Org Cult 10:197-208

Lema-Rumińska J (2011) Flow cytometric analysis of somatic embryos, shoots, and calli of the cactus Copiapoa tenuissima Ritt. forma monstruosa. Plant Cell Tissue Org Cult 106:531-535
Loureiro J, Pinto G, Topes T, Doležel J, Santos C (2005) Assessment of ploidy stability of the somatic embryogenesis process in Quercus suber L. using flow cytometry. Planta 22:815-822

Maheswaran G, Williams EG (1985) Origin and development of somatic embryoids formed directly on immature embryos of Trifolium repens in vitro. Ann Bot 56:619-630

Marie D, Brown SC (1993) A cytometric exercise in plant histograms, with $2 \mathrm{C}$ values for 70 species. Biol Cell 78:41-51

Marum L, Loureiro J, Rodriguez E, Santos C, Oliveira MM, Miguel C (2009a) Flow cytometric and morphological analyses of Pinus pinaster somatic embryogenesis. J Biotech 143:288-295

Marum L, Rocheta M, Maroco J, Oliveira MM, Miguel C (2009b) Analysis of genetic stability at SSR loci during somatic embryogenesis in maritime pine (Pinus pinaster). Plant Cell Rep 28:673-682

Masoud S, Hamta A (2008) Cytogenetic analysis of somaclonal variation in regenerated plants of Berseem clover (Trifolium alexandrinum L.). Caryologia 61:393-396

Moyne AL, Souq F, Yean LH, Brown SC, Boulay M, SangwanNorreel BS (1993) Relationship between cell ploidy and regeneration capacity of long term Rosa hybrida cultures. Plant Sci 93:159-168

Murashige T, Skoog F (1962) A revised medium for rapid growth and bioassays with tobacco tissue culture. Physiol Plant 15:473-497

Nagarajan P, Walton P (1987) A comparison of somatic chromosomal instability in tissue culture regenerants from Medicago sativa Pers. Plant Cell Rep 6:109-113

Ochatt SJ (2008) Flow cytometry in plant breeding. Cytometry A 73:581-598

Ochatt SJ, Mousset-Declas C, Rancillac M (2000) Fertile pea plants regenerate from protoplasts when calluses have not undergone endoreduplication. Plant Sci 156:177-183

Ochatt SJ, Muneax E, Machado C, Jacas L, Pontecaille C (2003) The hyperhydricity of in vitro regenerants of grass pea (Lathyrus sativus L.) with an abnormal DNA content. J Plant Physiol 159:1021-1028

Ochatt SJ, Patat-Ochatt EM, Moessner A (2011) Ploidy level determination within the context of in vitro breeding. Plant Cell Tissue Org Cult 104:329-341

Özcan S, Barghchi M, Firek S, Draper J (1993) Efficient adventitious shoot regeneration and somatic embryogenesis in pea. Plant Cell Tissue Org Cult 34:271-277

Parrott WA (1991) Auxin stimulated somatic embryogenesis from immature cotyledons of white clover. Plant Cell Rep 10:17-21

Pfosser M, Amon A, Lelley T, Heberle-Bors E (1995) Evaluation of sensitivity of flow cytometry in detecting aneuploidy in wheat using disomic and ditelosomic wheat-rye addition lines. Cytometry 21:387-393

Pinto G, Loureiro J, Lopes T, Santos C (2004) Analysis of the genetic stability of Eucalyptus globulus Labill. somatic embryos by flow cytometry. Theor Appl Genet 109:580-587

Prado MJ, Rodriguez E, Rey L, Gonzales MV, Santos C, Rey M (2010) Detection of somaclonal variants in somatic embryogenesis-regenerated plants of Vitis vinifera by flow cytometry and microsatellite markers. Plant Cell Tissue Org Cult 103:49-59

Ranch JP, Oglesby L, Zielinski AC (1986) Plant regeneration from tissue cultures of soybean by somatic embryogenesis. In: Vasil IK (ed) Plant regeneration and genetic variability. Cell culture and somatic cell genetics of plants, vol 3. Academic Press, Orlando, pp 97-110

Rival A, Beule T, Barre P, Hamon S, Duval Y, Noirot M (1997) Comparative flow cytometric estimation of nuclear DNA content in oil palm (Elaeis guineensis Jacq.) tissue cultures and seedderived plants. Plant Cell Rep 16:884-887 
Rodriguez APM, Wetzstein HY (1994) The effect of auxin type and concentration on pecan (Carya illinoiensis) somatic embryo morphology and subsequent conversion into plants. Plant Cell Rep 13:607-611

Rodriguez APM, Wetzstein HY (1998) A morphological and histological comparison of the initiation and development of pecan (Carya illinoiensis) somatic embryogenic cultures induced with naphtaleneacetic acid or 2, 4-dichlorophenoxyacetic acid. Protoplasma 204:71-83

Sanchez IC, Natali L, Cavallin A (1988) In vitro culture of Aloe barbadensis Mill.: morphogenetic ability and nuclear DNA content. Plant Sci 55:53-59

Shoemaker RC, Amberger LA, Palmer GR, Oglesby L, Ranch JP (1991) Effect of 2, 4-dichlorophenoxyacetic acid concentration on somatic embryogenesis and heritable variation in soybean (Glycine max (L.) Merr.). In Vitro Cell Dev Biol-Plant 27P: 84-88

Sofiari E, Raemaker CJJM, Kanju E, Danso K, van Lammeren AM, Jacobsen E, Visser RGF (1997) Comparison of NAA and 2, 4-D induced somatic embryogenesis in Cassava. Plant Cell Tissue Org Cult 50:45-56

Suhasini K, Sagare AP, Krishnamurthy KV (1996) Study of aberrant morphologies and lack of conversion of somatic embryos of chickpea (Cicer arietinum L.). In Vitro Cell Dev Biol 32:6-10

Sun Q, Sun H, Bell RL, Li H, Xin L (2011) Variation of phenotype, ploidy level, and organogenic potential of in vitro regenerated polyploids of Pyrrus communis. Plant Cell Tissue Org Cult 107:131-140

Tremblay L, Levasseur C, Tremblay FM (1999) Frequency of somaclonal variation in plant of black spruce (Picea mariana, Pinaceae) and white spruce ( $P$. glauca, Pinaceae) derived from somatic embryogenesis and identification of some factors involved in genetic instability. Am J Bot 86:1373-1381

Varga A, Thoma LH, Bruinsma J (1988) Effects of auxins and cytokinins on epigenetic instability of callus propagated Kalanchoe blossfeldiana Poelln. Plant Cell Tissue Org Cult 15:223-231

Vižintin L, Javornik B, Bohanec B (2006) Genetic characterization of selected Trifolium species as revealed by nuclear DNA content and ITS rDNA region analysis. Plant Sci 170:859-866

Wang H, Holl FB (1988) In vitro culture and incidence of somaclonal variation in regenerated plants of Trifolium pratense L. Plant Sci 55:159-167

Wetzstein HY, Baker CM (1993) The relationship between somatic embryo morphology and conversion in peanut Arachis hypogea L. Plant Sci 92:81-89

Yang JL, Seong ES, Kim MJ, Ghimre BK, Kang WH, Yu CY, Li CH (2010) Direct somatic embryogenesis from pericycle cells of broccoli (Brassica oleracea L. var. italica) root explants. Plant Cell Tissue Org Cult 100:49-58

Yang JL, Niu YD, Yang CP, Liu GF, Li CH (2011) Induction of somatic embryogenesis from female flower buds of elite Schisandra chinensis. Plant Cell Tissue Org Cult 106:391-399 